\title{
The Digital Griotte: Bessora's Para/Textual Discourses on Identity Politics and Neocolonialism in Contemporary France
}

\author{
Claire Mouflard \\ French and Francophone Studies Department, Hamilton College, Clinton, NY 13323, USA; \\ cmouflar@hamilton.edu
}

Received: 26 November 2018; Accepted: 29 December 2018; Published: 1 January 2019

\begin{abstract}
This article examines Bessora's literary and digital criticism of postcolonial France, particularly in her first novel, $53 \mathrm{~cm}$, and on her website, Tendre peau de vache. Bessora's use of digital media in particular allows her to chronicle unofficial discourses on immigration, migration, and identity politics in France as alternative textual productions to her printed novels. Since there is a gap in academic studies regarding author websites and their contents, this study aims to start a conversation on the discursive function of an author's digital textual productions. Following Jean Baudrillard's theory in The Spirit of Terrorism according to which a terrorist act is successful when it distances itself from the real and exalts itself in the realm of the symbolic, this article argues that Bessora's digital discourses on the post-Charlie Hebdo terrorist attack effectively denounce the disappearance of the real in French culture in favor of ideals such as the \#jesuischarlie movement. From the publication of $53 \mathrm{~cm}$ in 1999 to her commentaries on France's alienation of the lowest socio-economic class in Le Testament de Nicolas (2016), the self-proclaimed griotte's print and digital productions complement each other and bring the reader closer to an understanding of institutional neocolonialist practices in France.
\end{abstract}

Keywords: postcolonial; neocolonial; digital; France; Francophone; terrorism

\section{Introduction}

Belgian author Bessora remains, against all of the French publishing industry's best efforts to label her and her work, an auteure inclassable. Her printed productions as well as her authorial persona are impossible to categorize according to "traditional" standards: she is not essentially Gabonese nor Swiss (per her parents' nationalities), as she writes exclusively in French, and in part because of her Belgian citizenship, her work stands at the crossroads of the eternal debate between littérature française and littérature francophone. In this sense, Bessora and her works have been presented under various identifying labels over the years: in Gallimard's Continents Noirs collection, as an author of the Black diaspora (Cueillez-moi, jolis messieurs ... (Bessora 2007), Et si Dieu me demande, dites-lui que je dors (Bessora 2008)); as Francophone literature by Le Serpent à plumes (Citizen Narcisse (Bessora 2018b), La Dynastie des boiteux (Bessora 2018c)); and as fiction française ("French fiction") also by Le Serpent à plumes for her first novel, $53 \mathrm{~cm}$, first published in 1999. In truth, beyond all questions of personal and literary classification - which are often confused as being one and the same-Bessora's unique writing style has allowed her to overcome labels as she is constantly redefining her authorial voice through her various works.

From the story of a Belgian graduate student of Swiss-Gabonese descent trying to obtain a carte de séjour (French permanent residency card) in $53 \mathrm{~cm}$, to the latest Le Testament de Nicolas in which a young white French man decides to join the jihad in Syria, Bessora has made it her trademark to disconcert the 
French literary institutions and audience to claim her right to literary and personal self-determination. Through her print and now digital productions, Bessora has chronicled a widespread yet unrecorded dissident discourse on postcolonial France's identity and immigration politics, all the while denouncing the French population's passivity to neocolonial practices of segregation and xenophobia. From the literary sphere to the realm of national identity politics, Bessora has created a multidimensional discourse that denounces France's practices of neocolonialism which discriminate against immigrants and their descendants, as well as the lower socio-economic class.

This article is a study of Bessora's use of the digital medium via her personal blog and website Tendre peau de vache (which approximately translates as Sweet Nasty Cow). The digital paratext and epitext Bessora has created for herself outside of the mainstream literary and mediatic spheres have become textual productions that coexist with her published novels. According to Gérard Genette, the paratext is "what enables a text to become a book and to be offered as such to its readers and, more generally, to the public," and consists of all printed elements that exist outside of the text itself (the front cover image, back cover summary, table of contents, ... ) (Genette 1997, p. 2). Genette describes the epitext as all occurrences of discourse about the book, such as interviews or news articles, and he notes that " $(\ldots)$ ) the publisher's epitext and the semiofficial allographic epitext lie outside the declared responsibility of the author ( ... )" (Genette 1997, p. 351). While Genette's theories on the paratext and the epitext directly apply to the printed text itself, it is safe to assess that similar practices that can influence the formation of the author's public persona and his/her reception by the public also exist externally to the book. The author's paratext (formed of both concepts of paratext and epitext per Genette's definitions) has long been controlled by entities that are not the author him/herself: the publisher, the media, magazines, and even academic articles have created authorial personas for writers that exist beside their text and their authorial voice. In creating her own digital paratext, Bessora is claiming authority and agency over both her textual productions (print and digital) and her authorial identity.

In the commentaries she posts about current events, about her novels and her characters, and even in the direct messages she addresses to some of her characters, Bessora blurs the boundaries between text and paratext-between the textual production and the digital commentary. Her digital productions are varied, from blog posts relating her recent travels to a book festival in Brooklyn (Bessora 2018a) to a personal letter addressed to the character of one of her latest works, Nicolas of Le Testament de Nicolas. In taking control of her own paratext and of her oeuvre's, the self-proclaimed auteur lunatique à géographie variable (geographically variable and volatile author) has skirted the conventions that publishing houses typically impose on their authors in terms of marketing and audience formation. In all of her digital productions, one element surfaces beyond any doubt: the author's commitment to dispute, oppose, and deconstruct the established norms of literary, social, and cultural conduct in contemporary France.

This article will first establish Bessora's self-assumed role and mission as a griotte in contemporary France, as outlined in her first novel $53 \mathrm{~cm}$. A griot is a "West-African troubadour historian [whose] role has traditionally been to preserve the genealogies, historical narratives, and oral traditions of their people" (Britannica 2018). Despite Bessora's multifaceted and multicultural identity, the author attaches herself to the African notion of the griot (a term now commonly feminized as griotte), a keeper of records for future generations. In his article entitled "Griottes: Female Voices from West Africa," Thomas A. Hale explains that, despite the growing number and popularity of the griottes in contemporary West Africa, their function in society and in oral literature remains overlooked by literary critics and academics alike. Hale argues: "These female wordsmiths sing songs of praise and advice, serve as intermediaries in delicate interpersonal negotiations, and articulate the values of society at major social events" (Hale 1994, p. 71). From the publication of $53 \mathrm{~cm}$ in 1999 to her political commentaries and journaling of current events on her website, Bessora's self-assumed mission as the griotte of an undermined and unofficial France has transformed her authorial identity from that of a simple novelist to that of a digital humanist. Thus the final two sections of this article are dedicated to Bessora's online 
authorial identity and digital productions. In particular, this article focuses on Bessora's online reaction to the Charlie Hebdo terrorist attacks of 7 January 2015 and on the digital paratext created by the author around the publication of Le Testament de Nicolas (Bessora 2016a). This article's specific focus on two of Bessora's most politically-charged digital productions seeks to establish the author as a digital griotte whose strategic mastery of satire and the digital medium has confirmed as an unclassifiable author yet a prominent activist and humanist.

It is important to establish that there is a large gap in current scholarship regarding author websites and alternative digital productions as textual productions, particularly in the realm of Francophone Studies. On the other hand, a substantial number of publications have addressed the concepts of Black digital identity and authorship within the field of African-American Studies in the past ten years. Specifically, André Brock's “'Who do you think you are?': Race, Representation, and Cultural Rhetorics in Online Spaces" establishes that "[c]ompared to older forms of media, the Internet adds an interactive, discursive dimension to exterior renditions of Black identity and thus enabling interior perspectives on Black identity to become part of the conversation" (Brock 2009, pp. 15-16). In addition, Janell Hobson in "Digital Whiteness, Primitive Blackness: Racializing the "Digital Divide" in Film and New Media" discusses essentialist stereotypes linked to race, gender and internet usage as she argues that "a growing corpus of work by digital artists of color and web 2.0 participants has exposed [the] mythic constructions [situating blackness within a discourse of 'nature,' 'primitivism,' and pre-modernity] by reimagining blackness and womanhood beyond technological exclusion and surveillance" (Hobson 2008, p. 111). Collections focused on the digital experience of women in general, and women of color in particular, have also been produced, such as Beetham and Valenti's Blogging Feminism: (Web)Sites of Resistance (Beetham and Valenti 2007), and the more recent Women of Color and Social Media Multitasking: Blogs, Timelines, Feeds, and Community by Tassie and Givens (2015). Francophone Studies, especially Black Francophone Studies, have not however seen such an interest develop regarding the question of online identity formation in concurrence with the notions of race, gender, and social media usage. While this article is focused on one specific author and a selection of her blog posts, it therefore stands as a conversation opener regarding the various dynamics that are encompassed in these digital productions which exist in and at the intersections of the realms of race, ethnicity, gender, identity politics, immigration, postcolonialism and neocolonialism. The ultimate goal of this article is for academics to consider digital productions as integral parts of an author's corpus, as they represent alternative yet authentic commentaries on current events, especially in the realm of Francophone Studies. In addition, these digital works need to be perceived as pertaining to the author's agency over the design of her authorial persona's paratext, as well as the paratext of her oeuvre.

\section{2. "Black-Blanc-Beur," $53 \mathrm{~cm}$, and the Birth of the Griotte}

In her article "Bessora's Literary Ludics," Susan Ireland describes Bessora's first novel as "a kind of postmodern, semi-autobiographical narrative that deals with themes related to immigration in a farcical manner" (Ireland 2004, p. 7). In an attempt to describe the particular writing style and tone of the author, Ireland explains that "[t]he wide range of comic devices used in [her] texts-farce, irony, intertextual allusions, pastiche, parody, quiproquos, and every kind of wordplay imaginable-produces a generically hybrid form, a metafictional novel with an immigrant twist that reflects Bessora's own mixed origins and constitutes an innovative means of voicing her opposition to discourses of the past" (Ireland 2004, p. 7). At the turn of the millennium, Bessora was one of several francophone women writers (including Franco-Senegalese author Fatou Diome) who spoke up-or rather, "wrote up"-against the multicultural "Black-Blanc-Beur" (literally, "Black-White-Arab") utopia created by the media and the French public institutions following the men's soccer team win in the 1998 World Cup. The phrase "Black-Blanc-Beur" appeared in the summer of 1998 and quickly became a slogan supported by the French media and institutions in reference to the success of a supposedly multicultural French men's soccer team. "Black-Blanc-Beur" came to effectively replace the French flag 
colors of "Bleu-Blanc-Rouge" ("Blue-White-Red") that summer and glorified the athleticism of several players: "Black" defender Lilian Thuram whose two goals against Croatia in the semi-final helped qualify the French team for the final match; "Beur" midfielder Zinedine Zidane, whose two header goals, complete with Emmanuel Petit's third goal, won the final game against Brazil on the night of 12 July 1998, immediately turning him into a heroic figure whose portrait was projected onto the Arc de Triomphe with the headings "Champion du Monde" and "Zidane Président"; and of course, the "Blanc" players, who represented most of the 1998 team.

In $53 \mathrm{~cm}$, Bessora artfully unveils the reality of African immigrants in France: far from the idyllic version of immigration emphasized by the media after the "Black-Blanc-Beur" win, Bessora uses satire throughout her novel to shed light on the harsh reality of African people in France, from the difficult immigration process to the blatant racism they suffer at the hands of the French institutions. Served by the genre of autofiction, the 1999 novel positions the voice of the author as diametrically opposed to the official and utopian discourse on immigration at the turn of the millennium. The text itself tells the story of an immigrant in the "Black-Blanc-Beur" France of the late 1990s. 53 cm's main character Zara is struggling to obtain the required administrative paperwork, known as the carte de séjour (permanent resident card), which would allow both her and her daughter Marie to continue to live in Paris legally. In addition to the process being long and arduous, Zara learns in the first part of the novel that Marie does not even exist in eye of the French administration, as someone working for the CAF (the Caisse d'Allocations Familiales, a governmental entity that distributes allowances to families in France) informs her: "The Office of International Migrations (OMI) did not ask about your child, because foreign students do not have children. They come to France to study, and then go home, not to have children and stay in France. We thus no longer need the certificate from the OMI: you are a foreign student, single, with no dependent children" (Bessora 2001, p. 83). ${ }^{1}$ Through Zara, Bessora strives to unveil the hypocrisy and lack of humanity of postcolonial France's immigration system, at a time when multiculturalism in France was presented in the media as a reality that had already been achieved.

In fact, the populations that were most visibly portrayed in the media before 1998 were of African origin and constantly accused of causing unrest, which explains the media's focus on regulating the public image of "Blacks" and "Beurs" after 1998 in order to match the French population's elation after the World Cup victory. Beyond the terrorist attacks led by the GIA on the French territory during the Algerian Civil War, ${ }^{2}$ the political discourse on immigration at that time was also geared towards, or rather against, citizens of Sub-Saharan descent. In a 1991 discourse he made as mayor of Paris, Jacques Chirac infamously mentioned "le bruit et l'odeur," the "noise and smell" of immigrants from the African continent. Chirac explained:

The problem we have is not caused by foreigners, it is caused by an overdose. It may be true that there are not more foreigners than there were before the war, but they are not the same and that makes a difference. It is obvious that having Spanish, Polish, and Portuguese people

1 “L'OMI n'a rien demandé à votre enfant, parce que les étudiants étrangers n'ont pas d'enfants. Ils viennent en France pour faire des études et rentrer chez eux, pas pour faire des enfants et rester en France. Nous n'avons donc plus besoin du certificate OMI: vous êtes étudiante étrangère, célibataire et sans enfants" (Bessora 2001, p. 83).

2 The GIA (Armed Islamic Group), an Algerian terrorist organization active during the Algerian Civil War (1991-2002), claimed responsibility for the hijacking of an Air France flight in Marseilles on 24 December 1994, and for the murderous attack on the Saint-Michel metro station in Paris on 25 July 1995. For weeks after the attack, the face of then twenty-four-year-old French-Algerian Khaled Kelkal, believed to be the perpetrator of the bombing, was plastered on television screens and newspapers. After a lengthy televised assault by the French police on the apartment where Kelkal was hiding, he was killed on live television on 29 September 1995. Therefore, Zidane's scoring of two decisive goals in the World Cup final of 1998 not only brought victory to the team, it also enabled the creation of a nationalistic narrative focused on the successful son of Algerian immigrants, thus giving to "Beur" a new sense: that of obedience, integration, and national pride. 
working in our country poses fewer problems than having Muslims and Blacks. ${ }^{3}$ (Echchaibi 2011, p. 82)

In order to rectify this faux-pas, Chirac eventually profited from the men's soccer team's win in 1998 in publicly advertising his faith in a completely utopian vision of equality between the Français de Souche (the "truly French") and the formerly colonized and their children. It then quickly became clear that Chirac's adherence to the "Black-Blanc-Beur" slogan was not exactly sincere, but rather strategic in order to quiet the social unrest between France's "Blancs" on one side, and the "Blacks" and "Beurs" on the other. During the final match of the 1998 World Cup, Chirac was famously filmed in the presidential tribune mouthing the names of the players as they were announced on the field. The president was however instantly mocked for his lack of knowledge regarding the players' names, accused of profiting from the team's success in order to improve his own political ratings. During the traditional 14 July televised interview that year, immediately following the victory of the "Black-Blanc-Beur" team, Chirac was asked by two journalists if the "Black-Blanc-Beur" slogan reflected the government's intentions to curb racism and promote integration. Chirac did not directly address these pointed questions, but instead praised a "multicolored France" and spoke of a "people that needs to come together again, and to gather around an idea that makes them proud of who they are" (Chirac 1998, 1:55-2:50). ${ }^{4}$ The shift in Chirac's discourse concerning the "Blacks" and the "Beurs" was evidently politically motivated, and the president was extremely mindful of the potential that lied in the "Black-Blanc-Beur" slogan and utopia.

Against Chirac's post-1998 public revisionism regarding the reality of immigration in France, Bessora reminds her reader of the anti-African stereotypes that were born of the racist official images produced by French politicians in the 1990s. Therefore, Chirac's misstep about "le bruit et l'odeur" was not forgotten by Bessora a few years later when France was rejoicing in the victory of its "Black-Blanc-Beur" team. In the fifth chapter of $53 \mathrm{~cm}$, the narrator Zara recounts her frantic cleaning of the apartment where she and her daughter Marie are staying, as they prepare for a visit from an administrative official sent by the CAF to assess their living situation. Bessora writes:

I begin a procedure of deportation for this clandestine mess: smelly stuffed animals, various textiles "made in Taiwan," by enslaved children. There is also a tee-shirt "made in" manufacturing workshops by Asian slaves "made in Paris" ( ... ) I tie my hair which is, by the way, beautiful. I don't understand how foreigners with beautiful hair can be deportable; but in the prefectural reign, nobody gives a damn about hairiness ( ... ) An hour later, I have made good progress in my housework: the foreigner's house no longer stinks. ${ }^{5}$ (Bessora 2001, p. 23)

The hypocrisy of the French government and administration regarding the integration of African immigrants in the late 1990s was strongly denounced by Bessora who writes later in her work: "The Polish Jew can hide her Judaism. Luckily, she is not black; blackness inevitably disturbs the peace: it is visible ... I am an "acceptable Black." "Black," that's better than "Noir" it almost sounds like

3 “Notre problème, ce n'est pas les étrangers, c'est qu'il y a overdose. C'est peut-être vrai qu'il n'y a pas plus d'étrangers qu'avant la guerre, mais ce [ne sont] pas les mêmes et ça fait une différence. Il est certain que d'avoir des Espagnols, des Polonais et des Portugais travaillant chez nous, ça pose moins de problèmes que d'avoir des musulmans et des Noirs." (Echchaibi 2011, p. 82).

4 "un peuple qui a besoin de se retrouver ensemble, et de se retrouver autour d'une idée qui le rend fier de lui-même." (Chirac $1998,1: 55-2: 50)$.

5 “Je décide d'entamer une procédure d'expulsion de ce bordel clandestin: peluches malodorantes, divers textiles made in Taïwan, par les enfants esclaves. Il y a aussi un tee-shirt made in les ateliers de confection des esclaves asiatiques made in Paris ( ... J ) Je noue mes cheveux que j'ai d'ailleurs magnifiques. Je ne comprends pas que les étrangers qui ont de beaux cheveux soient expulsables; mais dans le règne préfectoral, tout le monde se fout de la pilosité ( . . . ) Une heure plus tard, j'ai bien avancé dans mon ménage: la maison de l'étranger ne pue plus"' (Bessora 2001, p. 23). 
"Blanc" [“White"], save for one letter" (Bessora 2001, p. 120). ${ }^{6}$ Published one year after the 1998 World Cup victory of the French soccer team, $53 \mathrm{~cm}$ therefore subtly and regularly denounces the utopic "Black-Blanc-Beur" slogan ("“"Black," that's better than "Noir"'), while focusing specifically on the French administration's rampant prejudice toward people of African origin.

Based on the interrogation to which $53 \mathrm{~cm}$ 's main character Zara had to submit at the OMI in order to apply for a carte de séjour, Bessora thus creates an imagined conversation between a version of Zara now turned OMI inspector and a cerise griotte, a sour, bitter type of cherry, therefore considered a fraud by the narrator. When talking to the cerise griotte, Zara, taking on the role of the inspector but truly the griotte in this scenario, asks, "Dear miss, as you claim to be a cherry, if you truly live in Cherryland, nothing proves that you are a resident there. Presumptions, only presumptions. And you demand a cherryness card!" to which the narrator comments: "My cherry does not provide proof of her cherryness. She also cannot be classified under the cherrysoïd family, and even less under that of the cherrymen: she aggravates her zoological case. Naturally. She also does not belong to the negroid subspecies. Naturally" (Bessora 2001, p. 19). ${ }^{7}$ The reference to the narrator's ethnicity and its historical denomination by French scientists in the eighteenth and nineteenth century ("la sous-espèce négroïde") is but one in a series of reflections from the narrator regarding the actual progress of multiculturalism in postcolonial France. Throughout her novel, Bessora artistically discredits the idealized all-inclusive (yet only opened to institutionally-formatted "Blacks" and "Beurs") France promoted in the "Black-Blanc-Beur" slogan through the use of rich literary devices such as that of the griotte.

The narrator of $53 \mathrm{~cm}$ reflects on her dual status as griotte later in the text as she comments on her writing of the novel (here, Bessora blurs the lines between fiction, autofiction, and autobiography), as well as her completing forms for the French institutions which will later decide on her and her daughter's worthiness to receive a carte de séjour. Bessora writes: “Tonight ( . . . ) I assume my role of griotte: at night, after hours, I narrate my epic. In the last episode, I volunteered to prove my motherhood with a postdated certificate of penetration. Because I am no longer a virgin; it is then possible that I am a mother, isn't it? It is then possible that Marie is my daughter, and that, then, she exists for real. The CAF made a mistake, didn't they"? (Bessora 2001, pp. 84-85). ${ }^{8}$ Here the role of the griotte is presented as twofold: as $53 \mathrm{~cm}$ is partly a work of autofiction (Zara's academic path closely mimics Bessora's), Zara writing her épopée ("epic" but also "journey" in colloquial French) while filling out official forms assimilates the cultural and historical pressures represented by the French administration with both the recording and creative process of the griotte. The recording process of the griotte thus intersects with the author's creative process, ultimately producing a unique multidimensional textual production and political commentary. In the end, the recording process of the

6 "La Polonaise juive peut cacher sa judaïté. Heureusement qu'elle n'est pas noire; la noireté trouble forcément l'ordre public: elle se voit ... Moi, je suis une Black acceptable. Black, c'est mieux que Noir:ça sonne presque Blanc, à une lettre près." (Bessora 2001, p. 120).

7 "Chère mademoiselle qui vous prétendez cerise, si vous habitez bien en Cerisie, rien ne prouve que vous y résidiez. Des présomptions, rien que des présomptions. Et vous réclamez une ca't de ceriseté! ( . . . ) Ma cerise n'apporte pas la preuve de sa ceriseté. Elle ne peut pas non plus être classifiée dans la famille des cerisoïdes, et encore moins dans celle des cerisiens: elle aggrave son cas zoologique. Naturellement. Elle n'est pas non plus de la sous-espèce négroïde. Naturellement." (Bessora 2001, p. 19).

8 “Ce soir ( . . ) je tiens mon rôle de griotte: le soir, à la veillée, je conte mon épopée. Au dernier épisode, je me proposais de prouver ma maternité par un certificat de pénétration antidaté. Car je ne suis plus vierge; il est donc possible que je sois mère n'est-ce pas? Il est alors possible que Marie soit ma fille, et que, donc, elle existe pour de vrai. La CAF s'est juste trompée n'est-ce pas?" (Bessora 2001, pp. 84-85).

9 There are many instances in $53 \mathrm{~cm}$ in which the family structure, the international moves, and the academic path of the narrator Zara follows Bessora's. For example, at the beginning of chapter 19, Zara narrates: "I am twenty-six years old. I left the bank eight months ago. I arrive in Paris for the second time. Ninon hosts me for a few weeks, until I find a furnished apartment. Without the $c^{\prime}$ 't de séjou', I am illegally registered in two universities: social anthropology and marketing strategy" "J'ai vingt-six ans. J'ai plaqué la banque il y a huit mois. Je débarque à Paris, pour la deuxième fois. Ninon m’héberge quelques semaines, le temps que je trouve un appartement meublé. Sans ca't de séjou', je suis illégalement inscrite dans deux facs: anthropologie sociale et stratégie marketing" (Bessora 2001, p. 122). Bessora herself studied at HEC (Haute Ecole de Commerce) in Switzerland before moving to Paris to study anthropology. 
griotte as well as the author's creative process of the novel are both disrupted by the institutions that weigh on the narrator's future in metropolitan France, turning the text itself into a political manifesto denouncing neocolonial administrative practices in the supposedly multicultural "Black-Blanc-Beur" France. After she tries to renew the carte de séjour she finally obtains through the French embassy in Switzerland (Bessora 2001, pp. 128, 132), Zara's legal status lapses and she is arrested by the police at the end of the novel, facing deportation.

\section{3. "Good Luck Charlie:" Deconstructing the Real, Digitizing the Symbolic}

Today, official discourses on immigration have not strayed too far from that of Chirac's in the 1990s, and of the French administration as reflected in $53 \mathrm{~cm}$. During the 2017 French presidential election, multiculturalism was in fact still considered a utopia by certain conservative politicians. For right and far-right candidates François Fillon and Marine Le Pen, multicultural France does not exist: there is only a France in which immigrants and their descendants have settled without integrating within the French Republican ideal. In a televised debate during the primaries, Fillon went as far as to declare to contender Alain Juppé: "No [France is not a multicultural nation]. France has a history, France has a language, France has a culture. Naturally, that culture and that language were enriched by contributions from foreign populations ( ... We did not choose communitarianism, or multiculturalism. This is not the choice that I want for my country." Fillon, who had served under former president Nicolas Sarkozy as prime minister, added that he "want[ed] foreigners who come to our country to integrate, assimilate, and respect our cultural heritage (... ) When you go to someone's house, common courtesy is to not take power" (Fillon 2016, 0:16-1:26) ${ }^{10}$.

Franco-Senegalese author Fatou Diome in Marianne Porte Plainte! (Marianne is suing! 2017) references both Fillon and Sarkozy when assessing the current state of affairs in France regarding the debate on national identity, heralded by Sarkozy when he was elected to the presidency in 2007. Ten years after the former president opened his Ministry of Immigration, Integration, National Identity and Co-development, Diome establishes in the first pages of Marianne: "So what about national identity?... If you ask a hundred of our countrymen what it means to them, you will end up with a hundred different versions of the Marseillaise [the French national anthem]. Disconsolate minds define and will always define this identity in the negative, in opposition to everything which, in their minds, embodies alterity" (Diome 2017, p. 18). ${ }^{11}$ Twenty years after the advent of the "Black-Blanc-Beur" utopia, the reality of multiculturalism and its link to France's colonial history continue to be debated, from the highest ranks of the government to the print and digital realms of contemporary literature.

In recent years, the significant migrations from Africa and the Middle-East into Europe have contributed to a renewed debate on national identity in France, as have the terrorist attacks that occurred throughout France, starting with the ISIS-perpetrated attack on the Charlie Hebdo magazine's headquarters in Paris on 7 January 2015. ${ }^{12}$ Since then, the disparaging tone used by politicians regarding immigration from France's former colonies in the 1990s has resurfaced and has been heavily applied to today's migrant populations, producing and broadcasting, for example, amalgams between first- and second-generation immigrants from the Maghreb, and the ISIS terrorists. Today, everyone, from average citizens to political leaders, from ISIS itself to the social activists of the Arab Spring,

10 “Non [la France n'est pas une nation multiculturelle]. La France a une histoire, elle a une langue, elle a une culture; naturellement, cette culture et cette langue se sont enrichies des apports de populations étrangères ( ... ) Nous n'avons pas fait le choix du communautarisme, du multiculturalisme. Pour ma part, ça n'est pas le choix que je veux pour mon pays. Je veux que les étrangers qui viennent s'installer dans notre pays s'intègrent, s'assimilent, respectent l'héritage culturel qui est le nôtre ( ... ) Quand on vient dans la maison d'un autre, par courtoisie, on ne prend pas le pouvoir." (Fillon 2016, $0: 16-1: 26)$.

11 "Alors, l'identité nationale?... Interrogez cent de nos compatriotes sur la conception qu'ils en ont, vous aurez cent versions possibles de La Marseillaise. Cette identité, les esprits chagrins la définissent et la définiront toujours par la négative, par opposition à tout ce qui, à leurs yeux, incarne l'altérité." (Diome 2017, p. 18).

12 The acronym ISIS stands for the Islamic State of Iraq and Syria. 
can participate in such debates thanks to the immediacy and far-reaching scope of social networks. The current rhetoric regarding immigration and national identity is therefore simultaneously created and shared on a much grander level than it was at the turn of the millennium. Social networks and websites have engendered a new type of discourse which, while it appears to exist in a symbolic and digital frame, is very real in its production and its impact on social and political events. Bessora has consequently adapted her writing and use of literary devices in order to match the current political discourse regarding the migrant and national identity crises in France, all the while keeping the immigrant question in focus, as it remains one of the main pillars and battlefields of identity politics today.

After the Charlie Hebdo terrorist attacks of 7 January 2015, Bessora published a piece on her website entitled "'Not in My Name:' Good Luck Charlie, et autres merdes de bison (Bullshit)." In the same way in which she had previously addressed the "Black-Blanc-Beur" utopia of 1998 and its repercussions in the French administrative realm in $53 \mathrm{~cm}$, Bessora once again uses satire and irony in her digital piece on "Charlie." When examining the author's writing style in $53 \mathrm{~cm}$, Susan Ireland had established that, "[s]ince Bessora's objective is to subvert discourses of the past, it is essential that her intention be recognized and that her use of literary devices such as irony not be taken seriously $(\ldots)$ Indeed, the relentless accumulation of comic exaggeration, farce, and word-play constantly signals to the reader that the conventions of realism have been abandoned" (Ireland 2004, p. 8). In fact, in the matter of Bessora's recent political commentary, it is indeed essential to consider her "relentless accumulation of comic exaggeration, farce, and word-play" as tools used to subvert the real and enter the realm of the symbolic.

In The Spirit of Terrorism published a short two months after the World Trade Center attacks of 2001, Jean Baudrillard explained that the only answer to the hegemonic North-American capitalist and cultural power as represented by the Twin Towers was terrorism, "terror against terror" (Baudrillard 2003, pp. 8-10). Baudrillard additionally affirmed that the $9 / 11$ terrorists were successful because they had chosen to attack the United States in the realm of the symbolic more than the real. Baudrillard thus wrote: "Never attack the system in terms of relations of force. That is the (revolutionary) imagination the system itself forces upon you-the system which survives only by constantly drawing those attacking it into fighting on the ground of reality, which is always its own. But shift the struggle into the symbolic sphere, where the rule is that of challenge, reversion and outbidding" (Baudrillard 2003, p. 17). Baudrillard further explained:

Among the other weapons of the system which they turned round against it, the terrorists exploited the 'real time' of images, their instantaneous worldwide transmission ( ... ) The role of images is highly ambiguous. For, at the same time as they exalt the event, they also take it hostage. They serve to multiply it to infinity and, at the same time, they are a diversion and a neutralization (this was already the case with the events of 1968). The image consumes the event, in the sense that it absorbs it and offers it for consumption. Admittedly, it gives it unprecedented impact, but impact as image-event. (Baudrillard 2003, p. 27)

The early 2000s' "image" has today effectively been replaced, or at least subverted, by social media content, especially by hashtag phrases which entice users to find commonality in the discussion or analysis of current events. In fact, the strategies and practices of the 9/11 terrorists as analyzed above by Baudrillard were effectively reproduced after the Charlie Hebdo attack, but not by the terrorists themselves: in saturating all discourses with the \#jesuischarlie slogan, politicians, social activists and citizens alike instantly broadcasted a symbolic notion of uniformity against the actual plurality of the country's social, cultural, and ethnic make-up.

Immediately after the attack at the magazine headquarters in Paris, the \#jesuischarlie hashtag began to spread or rather "trend" worldwide on social media platforms such as Facebook, Twitter and Instagram. The "Charlie" of the "Je suis Charlie" slogan and hashtag was made to represent the Republic and its ideals. The horror of the real attack was instantly replaced by a universally recognizable sign that sparked comments and debates regarding the Charlie Hebdo satirical cartoonists 
and their right to depict the Prophet Muhammad. Worldwide, "connected" civilians, politicians and artists on their online profiles expressed their horror, shock, agreement or disagreement with the root of the attack: were the Charlie Hebdo cartoonists expressing their right to free speech and satirical analysis of the current political and religious tensions between fundamentalists and the Western world, or were they wrongly bullying a portion of the population who already consider themselves as an unwanted minority in the France? In essence, \#jesuischarlie became a symbolic political identity marker, soon to be followed by \#jesuisahmed and other identifying hashtags derived from the tragedy. ${ }^{13}$ Ultimately, the French national identity debate had been revived, this time again serving the utopian ideal of a unified society; and yet, because of its digital nature, this debate allowed for an increased number of immediate counter-discourses. Unlike the "Black-Blanc-Beur" question of the early 2000s which could only be debated in the traditional news and print media or on television, \#jesuischarlie was created and expanded in the midst of a global, ultra-connected ongoing conversation.

In Media Control: The Spectacular Achievements of Propaganda, Noam Chomsky provides a critical analysis of the governmental use of public media in the modern Western world, and proposes that there are two types of democracy:

One conception of democracy has it that a democratic society is one in which the public has the means to participate in some meaningful way in the management of their own affairs and the means of information are open and free ... An alternative conception of democracy is that the public must be barred from the managing of their own affairs and the means of information must be kept narrowly and rigidly controlled. That may sound like an odd conception of democracy, but it's important to understand that it is the prevailing conception. (Chomsky 2002, p. 10)

While the "alternative conception of democracy" outlined by Chomsky, in which access and control of the media is allocated solely to the institutions, prevailed at the end of the twentieth century, the contemporary use of new media such as social sites Facebook and Twitter, or personal blogs like Bessora's Tendre Peau de Vache, provides individuals with the means to "participate in some meaningful way" in the national political discourse. Chomsky's concept of a "democratic society" is therefore realized in the era of digital media and textual productions, albeit for its constant and complex negotiation of identities and authority. In early 2015, at the peak of inescapable digital discourses on identity politics, non-Blanc authors were compelled to pick a side, to be or to not be Charlie, to publicly demonstrate complete adherence to the one and indivisible French Republican identity, or to denounce Charlie Hebdo's problematic publications and their questionable sense of humor in a divided yet undeniably multicultural postcolonial France. These authors' online posts and comments allowed them to participate in the discussion as well as define their personal and authorial identity outside of the official \#jesuisCharlie message.

Therefore, in "'Not in My Name:' Good Luck Charlie, et autres merdes de bison (Bullshit)" published online just five days after the Charlie Hebdo attack, Bessora imagines a French woman speaking to her, named Charlotte, who, after "crying ( . . . ) for some of the deceased but not all of them" is "demanding that [the author] be Charlie" (Bessora 2015, para. 1), ${ }^{14}$ in reference to the global outpouring of support for Paris, freedom of speech, and freedom of the press as expressed in the highly mediatized words "Je suis Charlie." In the wake of the attack, not all residents of France felt like they were Charlie. In fact, as she discusses her own status as a "cultural alibi" ("alibi culturel," Bessora 2015, para. 8) while denouncing her imaginary French friend Charlotte's hypocrisy, Bessora strongly

13 "\#jesuisahmed" was created to counter the uniform "\#jesuisCharlie" message in honoring Ahmed Merabet, the policeman who died during the attack while he was guarding the magazine's headquarters.

14 “Elle a beaucoup pleuré, ma Charlotte, pas tous les morts mais quelques-uns, qu'elle ne connaissait pas et n'appréciait guère, qu'elle ne lisait pas non plus. En état de transe, elle crie maintenant au génie, et me somme d'être Charlie." (Bessora 2015, para. 1) 
condemns the irony of the sudden "Je suis Charlie" patriotic impulse which purportedly denies the reality of multiculturalism and religious pluralism, and erases the inequalities born of the colonial-like relationship between France and its minority groups from the public's active memory.

Bessora refuses to commemorate or defend France's freedom of speech expressed in the "Je suis Charlie" slogan which she compares to the "Black-Blanc-Beur" motto when she writes: "[I didn't] light a candle, like I should have done after the Black-Blanc-Beur victory ( . . ) Deep suspicion in [Charlotte's] teary eyes: she used to classify me among the acceptable Blacks (café au lait, renegades), and she suddenly wonders if I could be a Muslim" (Bessora 2015, para. 3-4). ${ }^{15}$ In criticizing the hypocrisy of this imagined friend, Bessora exposes the generalized historical anti-Muslim sentiment in France. One that was only exacerbated by the all-encompassing yet ostracizing slogan of "Je suis Charlie." Bessora thus reminds her reader through her imagined friend Charlotte that most of the people who immediately adhered to the "Je suis Charlie" slogan would not have, at any other time or under any other circumstances, advocated quite this strongly for freedom of speech, equality of races and religions, and a general utopian sense of multiculturalism.

Bessora ultimately criticizes the social class of French residents to which Charlotte appears to belong. She decries the hypocrisy of all the "Charlottes" who suddenly manifested compassion for the victims of the attack, but never once expressed empathy for the habitual victims of France's social hierarchy who exist on the periphery, the descendants of immigrants:

She orders me to come march with her, in Paris. Why don't you go march in the projects! I said to her. It would be a change for you ... Silly, she answers, don't you know that République and Nation are in Paris proper? National unity is therefore very close to her place. Charlotte lives in national unity, which is contained in Paris. People from the projects, especially those from Grigny, live in world terrorism. So she will never set foot in Grigny.

(Bessora 2015, para. 2) ${ }^{16}$

In the same vein as $53 \mathrm{~cm}$ during her imagined conversation with the cerise griotte, Bessora relies here on satire in order to reveal to her reader the duplicity of people like Charlotte who only show national unity at strategic times and when encouraged by the media, and for whom "unity" does not actually encompass everyone, but a very select group of people. In having Charlotte overexplain to her the location of the République and Nation squares and metro stations-in what can be perceived as a stereotypical Parisian way, implying that Bessora is not exactly Parisian, being seen only as an "acceptable black" - Bessora satirically reveals that, in the mind of Parisians like Charlotte, the Republic and the Nation, meaning the State and symbolically France itself reside in Paris proper. This sense of self-righteousness from the higher white bourgeois class of France, as well as this class' complete disconnect with real events such as racism, terrorism, and migrations, inspired Bessora to write Le Testament de Nicolas, which was published only one year after the Charlie Hebdo attacks.

\section{Chronicling the Real and the Symbolic in Le Testament de Nicolas}

Le Testament de Nicolas, which can be translated as Nicolas' Will, Nicolas' Testament or even Nicolas' Legacy, was published in September 2016. This first-person narrative is written by Nicolas, a so-called Français de souche who does not come from a Muslim background, yet decides to join the jihad in Syria. This print publication appears to have been informed directly by Bessora's aforementioned online reaction to the Charlie Hebdo attacks of 2015. In "Not in My Name," she had defended

15 “[Je n'ai] Pas non plus allumé ma petite bougie, comme j'aurais déjà dû le faire après la victoire Black-Blanc-Beur de 98 [ ... . ] Grave soupçon dans ses yeux moites: elle qui me classait parmi les Blacks acceptables (cafés au lait, et autres renégats), elle se demande soudain si je ne serais pas musulmane." (Bessora 2015, para. 3-4)

16 “Elle m'enjoint aussi de marcher avec elle, à Paris. Va donc marcher en banlieue ! je lui dis. Ca te changerait... Nigaude, elle me répond, tu ne savais pas que République et Nation étaient à Paris? L'unité nationale se trouve donc tout près de chez elle. Charlotte habite l'unité nationale, qui se trouve circonscrite à Paris. Les banlieusards, surtout ceux de Grigny, vivent dans le terrorisme mondial. Alors elle ne mettra jamais les pieds à Grigny." (Bessora 2015, para. 2) 
the multiplicities of "French" identities in the wake of a singular national identification movement promoted in the mediatized slogan "Je suis Charlie," while singling out the persistent anti-Muslim sentiment that was deeply ingrained in the metropolitan French social fabric. In Le Testament de Nicolas, Bessora positions her lead character, Nicolas, as a victim of the current socio-cultural malaise that has become poignant among the younger working-class French generation. Nicolas thus explains to his younger sister Salomé that there is "no future" for him in France, and that "everything he could dream of here, he will never have it," which is why he prepares for his departure, "to become who [he is]" (Bessora 2016a, pp. 23-24). ${ }^{17}$

Via Nicolas' voice, Bessora denounces the omnipresence of the symbolic in contemporary French culture, and the ways in which it has not only replaced the real, but also created a generalized sense of apathy among the French population. Speaking directly to his younger sister Salomé in his journal, Nicolas writes: "True heroes are invisible. No one can see them, yet almost everyone wants to get rid of them. In rags, they beg or sell you counterfeits. Those heroes have walked across half of Africa or two thirds of the Middle East, but they do not inspire anyone. They should have sailed on the Route du Rhum or cycled around the world. Or win that TV show Survivor, why not" (Bessora 2016a, p. 21) ${ }^{18}$ In direct reference to the very real migrant crisis that arose after the beginning of the Syrian civil war in 2011, and to other migrations of populations who fled their homeland because of terrorism and genocide, Bessora criticizes through Nicolas' voice the cult of the entertainment media which a large portion of the French population accepts without questioning.

Jean Baudrillard, who established that the attack on the Twin Towers in 2001 was a success for the terrorists because it impacted the West in the realm of the symbolic rather than only the real, exposes the "murder of the real" in The Vital Illusion (Baudrillard 2000). For Baudrillard, the "murder of the real" or what he calls "the Perfect Crime" takes place in the realm of virtual reality, a realm in which we could classify Bessora's digital productions. Citing Guy Debord's La société du spectacle (Debord 1967) and his concept of "spectacle and spectacular alienation" (Baudrillard 2000, p. 66), Baudrillard explains the evolution of our world into the realm of virtual reality as the immediate replacement of the Real:

For Debord, there was still a chance of disalienation, a chance for the subject to recover his or her autonomy and sovereignty. But now this radical Situationist critique is over. By shifting to a virtual world, we go beyond alienation, into a state of radical deprivation of the Other, or indeed of any otherness, alterity, or negativity ( ... ) We are dealing with an attempt to construct an entirely positive world, expurgated of every illusion, of every sort of evil and negativity, exempt from death itself. This pure, absolute reality, this unconditional realization of the world-this is what I call the Perfect Crime. (Baudrillard 2000, pp. 66-67)

In alienating French spectators from the reality of migration and its causes, the media contributes, with shows such as Survivor ("Koh-Lanta" in France), to the longevity of the symbolic over the real. If contemporary media, as Bessora's character Nicolas underlines, completely ignores and erases the real by replacing it with the symbolic, then Bessora, in commenting about the real through her digital productions, draws her reader's attention to the real's disappearance. In publishing overt critiques and analyses of current real phenomena on her blog, phenomena which are not addressed in contemporary media, Bessora simultaneously enters a symbolic war and a war on the symbolic-one modeled after that which Baudrillard imagined after the 2001 attack on the Twin Towers. Because her critique of current events is taking place in virtual reality (Baudrillard), Bessora could be accused of unwittingly

17 "Aucun avenir ici. Tout ce dont je pourrais rêver ici, je ne l'aurai jamais ( ... ) Je suis en route dans ma tête, pour devenir qui je suis." (Bessora 2016a, pp. 23-24)

18 "Les vrais héros sont invisibles. Personne ne les voit, tout le monde à peu près veut s'en débarrasser. En guenilles, ils mendient ou te vendent de la contrefaçon. Ces héros-là ont traverse la moitié de l'Afrique ou les deux tiers de l'Orient à pied, mais ils ne font rêver personne. Ils auraient dû faire la route du Rhum ou le tour du monde à vélo. Gagner Koh-Lanta, aussi." (Bessora 2016a, p. 21) 
partaking in the "Perfect Crime." However, since her digital productions now coexist with her print publications (as exemplified with Le Testament de Nicolas), it is evident that Bessora is not looking to aid in the disappearance of the real, but rather utilizes the digital platform in order to point her online reader, who is caught within the realm of the symbolic, in the direction of the real.

At the very bottom of the webpage dedicated to the novel and simply titled "Nicolas," the online reader encounters the very first post of the page entitled "Birth of a Monster" ("Naissance d'un monstre"), published on 29 August 2016-the novel itself was published on 1 September 2016 by La Margouline. In this post, Bessora addresses her character Nicolas directly. She explains that she found inspiration for his character in news of young men leaving their families behind in France in order to join the jihad in Syria. In addressing Nicolas as if he were real in an online letter, Bessora creates a bridge between the symbolic and the real which allows her to call her reader's attention to the very materiality of all the "Nicolas" who never felt comfortable in contemporary France, despite their seemingly obvious white privilege. Bessora writes:

I started to write you in the fall of 2014. At that time, people talked a lot about boys and girls who, like you, were leaving. They often ended up torn apart while defending bizarre ideas. I remember a blond boy who surprised a lot of people. Neither Arab nor "truly" Muslim [de souche], he had sinned ( ... ) You were a white boy, an unintegrated white boy. You rejected your father, your mother, low-waged slaves. You rejected society's liberalism, your rejected school, where you were not allowed to talk ( . . ) You hoped for a better world. So you left. ${ }^{19}$ (Bessora 2016b, para. 1-5)

Bessora then establishes that the new and better life for which her character left France turned out to be an imitation of the social structure he despised in the West. She explains: "In the Sham, people were unable to truly invent new values. In the Sham, people could not really change their lifestyle. In the Sham, people were just as dumb as here. But worse. A caricature (... ) Over there, just like here, the established order in not questioned" (Bessora 2016b, para. 6-7). ${ }^{20}$

At the end of her letter to Nicolas, Bessora references another one of her characters, Alpha, from her graphic novel Alpha: Abidjan-Gare du Nord (Bessora 2014), co-written with French illustrator Barroux. ${ }^{21}$ With Alpha, Bessora could have chosen to discuss the migrant crisis from the Middle-East to Europe, but instead chose to focus on the dangerous passage of an immigrant from the Ivory Coast on his way to Paris, where he hopes to be reunited with his wife and son. Bessora's reference to Alpha in her letter written to her character Nicolas in the blog post "Birth of a Monster" openly brings the two male characters together as the contemporary indirect victims of France's colonial history, and of neocolonialist global practices which are born of that history. Bessora writes: "Do you remember Alpha, the migrant? Like you, he had no future. He thought he could find a better world in Europe. Abidjan-Paris, his path of disillusionment. Paris-Alep, yours" (Bessora 2016b, para. 8). ${ }^{22}$ Like Alpha, Nicolas finds that life in the jihad is not as rewarding as he first imagined. As Bessora notes in her letter to him:

19 “J'ai commencé à t'écrire à l'automne 2014. On parlait beaucoup, à l'époque, des filles et des garçons qui comme toi partaient. Ils finissaient souvent déchiquetés pour de drôles d'idées. Je me souviens d'un blondinet qui avait étonné. Ni Arabe, ni musulman de souche, il avait fauté ( ... ) Tu étais un petit Blanc, un petit Blanc désintégré. Tu rejetais ton père, ta mère, des esclaves mal salariés. Tu rejetais le libéralisme de la société, tu rejetais l'école, où tu ne pouvais pas parler (... ) Tu avais l'espoir d'un monde meilleur. Alors tu es parti." (Bessora 2016b, para. 1-5).

20 "Au Sham, on n'arrivait pas vraiment à inventer de nouvelles valeurs. Au Sham, on ne changeait pas réellement de mode de vie. Au Sham, on était les mêmes cons qu'ici. En pire. En caricature ( . . ) Et puis là-bas comme ici, on ne remet pas en question l'ordre établi." (Bessora 2016b, para. 6-7)

21 Alpha is a community project geared toward a younger, international public. It was translated from French into English in 2016 and the translation was published by Amnesty International.

22 "Te souviens-tu d'Alpha, le migrant? Lui comme toi, pas d'horizon. Son monde meilleur, il pensait le trouver en Europe. Abidjan-Paris, son chemin de disillusion. Paris-Alep, le tien." (Bessora 2016b, para. 8) 
You hoped for a better world. So you left. Toulouse, Antalaya, Alep ... The closer you were getting to your ideal world, the more it was slipping away (... ) You could tell, but you did not want to admit it. Besides Emmanuel, besides Souleymane, the boys and girls around you did not see it. And over there, just like here, one should not question the established order.

(Bessora 2015, para. 5-7) ${ }^{23}$

Ultimately, Nicolas dies in a suicide mission in Paris. Hoping to reach the heavens in becoming a martyr, Nicolas only finds suffering in taking the lives of seventeen innocent people with him: "Convinced that his soul weighs $21 \mathrm{~g}$, certain that some martyrs smell like musk as they die, he leaves and starts driving a truck filled with $2500 \mathrm{~kg}$ of explosives. He thinks about Salomé ( . . ) But the second the explosion happens, there are no glorious skies. Only unspeakable suffering, and seventeen lives that die with him" (Bessora 2016a, p. 178). ${ }^{24}$ The end of the printed novel brings the reader back to the real—the terrorist attack, the explosion, the lives lost—while Bessora's digital letter to Nicolas takes the form of the author's own testament (will, testament, legacy), a symbolic reunion of sorts among the Others of the French Republic: Bessora, Zara, Nicolas, and Alpha. The critical blending of the real and the symbolic was described by Baudrillard as the height of what he had termed "the spirit of terrorism" in 2001:

In this case, then, the real is superadded to the image like a bonus of terror, like an additional frisson: not only is it terrifying, but, what is more, it is real. Rather than the violence of the real being there first, and the frisson of the image being added to it, the image is there first, and the frisson of the real is added. Something like an additional fiction, a fiction surpassing fiction. Ballard (after Borges) talked like this of reinventing the real as the ultimate and most redoubtable fiction. (Baudrillard 2003, p. 29)

Here what Baudrillard terms the "image," which in this study takes the form of Bessora's digital letter to Nicolas, comes first in its immediacy as a globally available online production, while the representation of the real in the novel itself, the "frisson of the real," comes second. In this sense, Bessora has mastered the mechanisms of "the spirit of terrorism." She effectively uses both the symbolic and the real, as characterized by both her print and digital textual productions, to counteract the effects of the discursive and political war on Others in contemporary France. In addition, the preexistence of her digital piece, published online four days before the novel became available for purchase in bookstores, aligns itself with the steps taken by the terrorists in Baudrillard's study. Bessora is of course not a terrorist, nor should she be positioned on the side of the actor of terror. Rather, she has mastered the mechanisms of discursive terrorism which have allowed her to confront today's global ideology of neocolonialism and respond to the many institutional terrors inflicted on Others in France-the non-Blanc, the immigrant, the lower social class.

\section{Conclusions}

Bessora's digital productions have, over the years, become an integral part of both her creative writing portfolio and her public persona. In taking control of her digital paratext, Bessora has been able to address events and concepts which might not have been considered proper for publication, such as her discourse on neocolonialism and the French hypocrisy in relation to the Charlie Hebdo

23 “Tu avais l'espoir d'un monde meilleur. Alors tu es parti. Toulouse, Antalaya, Alep ... Plus tu te rapprochais de ton monde idéal, plus il se dérobait $(. .$.$) Tu t'en rendais compte, mais tu ne voulais pas le voir. A part Emmanuel, à part Souleymane,$ les filles et les garçons autour de toi ne le voyaient pas. Et puis là-bas comme ici, on ne remet pas en question l'ordre établi." (Bessora 2016b, para. 5-7).

24 “Convaincu d'être doté d'une âme pesant 21 grammes, certain que les martyrs dégagent une odeur de musc au moment de leur mort, il sort, prend le volant d'un camion chargé de $2500 \mathrm{~kg}$ d'explosifs. Il pense à Salomé ( ... ) Mais à la seconde de l'explosion, ce ne sont pas les ciels scintillants. C'est la souffrance indicible, et dix-sept vies qui s'éteignent avec lui." (Bessora 2016a, p. 178) 
attacks. The self-created digital griotte has thus established alternative historical records that reflect another side of, for example, the Charlie Hebdo attacks, in documenting the irony and hypocrisy of the "Je suis Charlie" slogan as felt by the non-Blanc French. The history and persistence of the anti-Muslim sentiment in France was then elaborated upon in her novel Le Testament de Nicolas, all the while giving it a digital presence in her direct address to the character, and producing a form of digital mending of the neocolonial woes that bind together the victims of islamophobia, racism, and neocolonialism in postcolonial France. The chronology of Bessora's print and digital political commentary continues to follow France's desire to be recognized as postcolonial and multicultural despite the French institutions' repetitive productions of utopian multiculturalism and postcolonialism. Beyond her own need to step outside of the confines of literary classification, Bessora is working to subvert the official discourse on immigration politics in France with the publication of her online chronicles, as this century's first digital griotte.

Funding: This research received no external funding.

Conflicts of Interest: The author declares no conflict of interest. Apart from the references indicated below, all translations are the author's.

\section{References}

Baudrillard, Jean. 2000. The Vital Illusion. Edited by Julia Witwer. New York: Columbia University Press. Available online: www.jstor.org/stable/10.7312/baud12100 (accessed on 23 October 2018).

Baudrillard, Jean. 2003. The Spirit of Terrorism. Translated by Chris Turner. London: Verso. First published 2002.

Beetham, Gwendolyn, and Jessica Valenti. 2007. Blogging Feminism: (Web)Sites of Resistance. Scholar and Feminist Online 5: 2. Available online: http://sfonline.barnard.edu/blogs/index.htm (accessed on 23 December 2018).

Bessora. 2001. $53 \mathrm{~cm}$. Paris: Le Serpent à plumes. First published 1999.

Bessora. 2007. Cueillez-Moi, Jolis Messieurs ... . Paris: Gallimard.

Bessora. 2008. Et si Dieu me demande, dites-lui que je dors. Paris: Gallimard.

Bessora. 2014. Alpha: Abidjan-Gare du Nord. Paris: Gallimard.

Bessora. 2015. 'Not in My Name:' Good Luck Charlie, et autres merdes de bison (Bullshit). Tendre peau de vache. Available online: https:/ /bessora.fr/2015/01/12/not-in-my-name-et-autres-merdes-de-bison-bullshuit/ (accessed on 23 October 2018).

Bessora. 2016a. Le Testament de Nicolas. Paris: La Margouline.

Bessora. 2016b. Naissance d'un monstre. Tendre peau de vache. Available online: https://bessora.fr/2016/08/29/ terrorisme-radicalisation-djihadisme-suicide/\#comments (accessed on 29 October 2018).

Bessora. 2018a. Bons Baisers de Brooklyn. Tendre peau de vache. Available online: https:/ / bessora.fr/2018/09/24/ bons-baisers-de-brooklyn / (accessed on 23 November 2018).

Bessora. 2018b. Citizen Narcisse. Paris: Le Serpent à Plumes.

Bessora. 2018c. La Dynastie des boiteux. Paris: Le Serpent à Plumes.

Britannica. 2018. Griot. Britannica Online Academic Edition. Available online: http:/ /academic.eb.com/levels/ collegiate/article/472465 (accessed on 24 November 2018).

Brock, André. 2009. 'Who Do You Think You Are?': Race, Representation, and Cultural Rhetorics in Online Spaces. Poroi: Project on Rhetoric of Inquiry 6: 15-35. [CrossRef]

Chirac, Jacques. 1998. Interview du Président de la République Jacques Chirac. Journal de 13h. Video, 1:55-2:50, Posted by INA. Available online: https://www.ina.fr/video/CAB98029177 (accessed on 21 November 2018).

Chomsky, Noam. 2002. Media Control: The Spectacular Achievements of Propaganda. New York: Seven Stories Press.

Debord, Guy. 1967. La Société du Spectacle. Paris: Gallimard.

Diome, Fatou. 2017. Marianne Porte Plainte! Paris: Flammarion.

Echchaibi, Nabil. 2011. Voicing Diasporas: Ethnic Radio in Paris and Berlin between Cultural Renewal and Retention. Lanham: Lexington Books. 
Fillon, François. 2016. La France n'est pas une nation multiculturelle. Primaire: Le grand débat. Video, 00:16-1:26, Posted by RTL. Available online: https:/ / www.rtl.fr/actu/politique/francois-fillon-la-france-n-est-pasune-nation-multiculturelle-7785965830 (accessed on 24 November 2018).

Genette, Gérard. 1997. Paratexts: Thresholds of Interpretation. Cambridge: Cambridge University Press.

Hale, Thomas A. 1994. Griottes: Female Voices from West Africa. Research in African Literatures 25: 71-91. Available online: www.jstor.org/stable/3819846 (accessed on 1 November 2018).

Hobson, Janell. 2008. Digital Whiteness, Primitive Blackness: Racializing the "Digital Divide" in Film and New Media. Feminist Media Studies 8: 111-26. [CrossRef]

Ireland, Susan. 2004. Bessora's Literary Ludics. Dalhousie French Studies 68: 7-16. Available online: www.jstor.org/ stable/40836849 (accessed on 1 November 2018).

Tassie, Keisha Edwards, and Sonja Brown Givens. 2015. Women of Color and Social Media Multitasking: Blogs, Timelines, Feeds, and Community. Lanham: Lexington Books.

(C) 2019 by the author. Licensee MDPI, Basel, Switzerland. This article is an open access article distributed under the terms and conditions of the Creative Commons Attribution (CC BY) license (http:/ / creativecommons.org/licenses/by/4.0/). 